\title{
Do Caos à espuma: o sinuoso percurso de Afrodite
}

From Chaos to foam: the wavy path of Aphrodite

Juan Manuel Terenzi ${ }^{1}$ 


\section{Resumo}

Neste artigo, propomos uma leitura acerca da deusa Afrodite e de suas múltiplas análises e interpretações ao longo da história. Sua potência interpretativa tem sido explorada em diversas manifestações artísticas, como na literatura, na pintura, na escultura, entre outras. Desta forma, buscamos num primeiro momento discutir sua imersão no mundo grego através da cosmogonia de Hesíodo, passando por Platão para, finalmente, expandir sua leitura até o olhar contemporâneo de Didi-Huberman. Logo, a proposta deste trabalho consiste em refletir sobre a diversidade interpretativa que acompanha a presença de Afrodite na arte.

Palavras-chave: Afrodite; história da arte; Didi-Huberman

\section{Abstract}

In this article we propose a reading about the goddess Aphrodite and her multiple analysis and interpretations along the history. Her hermeneutical power has been exploited in many artistic manifestations, e.g. literature, painting, sculpture, among others. In this way, first we discuss her immersion in the Greek world through the hesiodic cosmogony, as well as the platonic reading. Then, we expand this reading until it reaches the contemporary French critic Didi-Huberman. Therefore, we wish to unveil the interpretative richness that is inherent in Aphrodite.

Keywords: Aphrodite; history of art; Didi -Huberman.

ISSN: 1808-3129 


\section{A gênese dos deuses, 0 caos e o olho}

Nesta primeira parte, verificaremos como Afrodite, deusa grega associada à beleza, possui uma das gêneses mais conturbadas entre os deuses provenientes do imaginário grego antigo. Entretanto, antes de adentrarmos neste conflituoso nascimento e suas consequências, convém fazer uma breve excursão pela cosmogonia grega, escutando os versos de Hesíodo:

Sim bem primeiro nasceu Caos, depois também

Terra de amplo seio, de todos sede irresvalável sempre, dos imortais que têm a cabeça do Olimpo nevado, e Tártaro nevoento no fundo do chão de amplas vias, e Eros: o mais belo entre Deuses imortais, solta-membros, dos Deuses todos e dos homens todos ele doma no peito o espírito e a prudente vontade. [...] (HESÍODO, 2007, p.109)

Após Hesíodo invocar as Musas e render-lhes cento e quinze versos para auxiliá-lo no canto dedicado à gênese dos deuses, irrompe no poema o ponto negro da origem. Com um enfático "sim", que em grego arcaico se diz n̆тoı (étoi) e que semanticamente assinala a certeza do que vem dito a seguir, o poeta assegura-nos de que antes de tudo nascera Caos ${ }^{1}$. Mas ainda reside uma origem por trás de Caos, conforme o verbo empregado para demarcar a sua proveniência. Caos nasce primeiro. Permanece a questão: de quem ele nasce? Isto Hesíodo não nos responde, ou melhor, nos aflige com a incerteza da origem. Lascaux e a era do gelo eterno já assinalara o drama que implica em não identificar a causa primeira da pintura e do aspecto lúdico inerente ao Homo Ludens; por sua vez, o mundo grego e um dos primeiros aedos (juntamente com Homero) nos coloca em confronto com o insondável Caos.

Antonin Artaud ao discorrer sobre o que ele denomina de crueldade na carta escrita a A. M. R. de R. revela que: “El bien está siempre en la cara exterior, pero la cara interior es el mal. Mal que eventualmente será reducido, pero sólo en el instante supremo, cuando todo aquello que fue forma se encuentre a punto de retornar al caos." (ARTAUD, 2001, p.104). O ponto de vista 'caótico' de Artaud abole a passividade advinda da ordem, do kosmos, cujo significado em grego remete tanto à beleza quanto ao ordenamento, a boa ordem e ao asseio. A arte estaria desta forma preocupada não em desvendar o segredo do início de tudo, restabelecendo por sua vez a certeza de um ponto original.

Pelo contrário, ela se alimenta da voracidade do Caos, ciente de que na sua incerteza habita a infinidade de possibilidades. Nietzsche pode ser considerado como o primeiro filósofo a romper as ataduras que prendiam a filosofia, desde Aristóteles, à causa primeira². Em Além do bem e do Mal, no final do fragmento 205, o filósofo alemão descreve o que ele entende pela expressão 'verdadeiro filósofo':

${ }^{1}$ HESIOODO. Teogonia. Estudo e Tradução de Jaa Torrano. São Paulo:

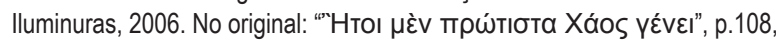

2 Aristóteles ao encerrar o livro $\lceil$ da Metafísica identifica a causa primeira com Deus (тò прштоv KIvoũv ákívntov aủió, p.214 1012b31), aquele que move todos os demais entes (pois ele seria desejado), sem ele próprio ser movivel por nada. "[...] pues hay algo que siempre mueve las cosas que se mueven, y el primer Motor es inmóvil él mismo" in: ARISTÓTELES. Metafísica. Edición trilingüe, traducción de Valentín García Yebra. Madrid: Gredos, 1982, p.215. 
Mas o verdadeiro filósofo - pelo menos assim nos parece, não é mesmo, meus amigos? - vive de um modo "não-filosófico", não-sábio", e sobretudo imprudentemente. E sente o fardo e o dever de inumeráveis tentativas e tentações da vida. Arrisca-se constantemente. Joga o grande jogo. (NIETZSCHE, 2006, p.102)

No fragmento escolhido, a vida é posta na condição de jogo, mais ainda, ela é considerada como o 'grande jogo'. É muito provável que Nietzsche esteja seguindo uma linha de raciocínio fortemente influenciada por Heráclito que no fragmento 52 relaciona o tempo (áıùv), que entre outros significados destaca-se a ideia de tempo

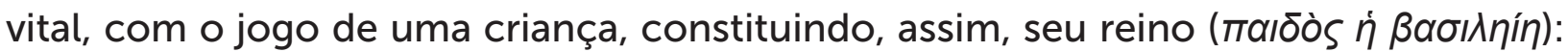
"El tiempo vital es un niño que juega tirando los dados; el reino de un niño" (HERÁCLITO, 2008, p.221). Este fragmento de Heráclito também se relaciona com o poema de Mallarmé "Un coup de dés jamais n'abolira le hasard" pelo aspecto lúdico presente em ambos. O poeta, assim, lança as palavras no espaço limitado das páginas à maneira de dados, desafiando a leitura linear do leitor ingênuo.

Retomando o pensamento de Nietzsche, percebe-se que muitas vezes ele é mal compreendido e julgam-no inconsequente e megalomaníaco. Mas ressoam em suas palavras o vigor das pinturas encontradas em Lascaux, e percebemos a dança rítmica que delas emana. Vida e arte encontram-se unidas de tal forma em Nietzsche que torna-se difícil dissociar a faceta autobiográfica de seus escritos.

Outro detalhe particular deste filósofo-artista é que ele recorrentemente assume uma postura distanciada das comodidades do pensamento e, assim, pertenceria às 'alturas gélidas' da reflexão especulativa, "Quem sabe respirar o ar de meus escritos sabe que é um ar das alturas, um ar forte" (NIETZSCHE, 2008, p.16). Além de ver-se apoiado constantemente na certeza que dele emerge, adota um pensamento que de certa forma vai contra o cunho científico proposto pela filosofia aristotélica e que até hoje serve de modelo à Ciência. O pensamento nietzschiano reivindica preferencialmente determinados filósofos gregos, a saber: "É preciso coragem para admitir que o mundo moderno se ressente da falta de filósofos como Heráclito, Platão, Empédocles, e de todos os outros sublimes eremitas do espírito" (id., 2006, p.100). Nietzsche se volta aos primeiros pensadores na tentativa de lá encontrar os ares frescos do pensamento, embora seja este um caminho árduo. Em nossa tentativa de visualizar a herança do mundo antigo, os versos de Hesíodo dão testemunho da dificuldade encontrada pelo poeta em revelar esse ponto negro de nossa identidade, que pode ser associado com o opúsculo escrito por Georges Bataille em 1927, L'anus solaire. Neste pequeno texto, a dimensão poética perpassa as palavras, enquanto já identificamos no jovem Bataille a interessante associação entre o erotismo cósmico tendo o Sol como figura fálica e a natureza ávida em procriar-se e direcionar-se rumo a essa fonte de luz espermática. De acordo com o escritor francês, uma das fraquezas do homem está na impossibilidade de fitar o Sol com os olhos nus. Esta leitura batailliana mostra-se em íntimo contato com o livro VII da República de Platão, quando é discutido o mito da caverna, em que se considera o nosso mundo como aquele imerso

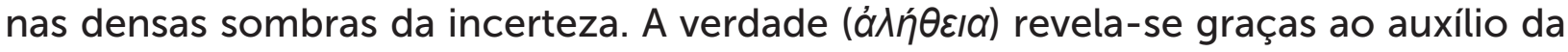
'luz original' emanada do corpo solar permitindo que os objetos sejam vistos na sua maior perfeição possível; para isto o filósofo deve abandonar a caverna para posteriormente instruir os ignorantes que se iludem no mundo das sombras, acreditando 
que estas mesmas sombras representariam os verdadeiros objetos do mundo. Outra associação encontrada na República é entre o olho humano e o formato do Sol, discutida pouco antes do mito da caverna, precisamente no final do livro VI em um diálogo travado entre Glauco e Sócrates:

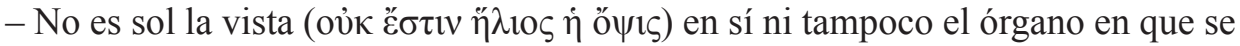
produce, al cual llamamos ojo (ő $\mu \mu \alpha)$.

- No en efecto.

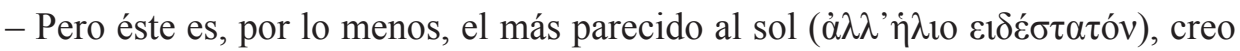

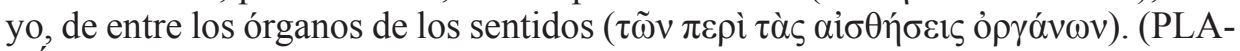
TÓN, 2005, p.396)
}

Ainda situando-nos no mundo grego arcaico, Aristóteles, discípulo de Platão, inicia o livro A da Metafísica com a conhecida frase:

Todos los hombres desean por naturaleza saber. Así lo indica el amor a los sentidos; pues, al margen de su utilidad, son amados a causa de sí mismos, y el que más de todos, el de la vista. [...] éste es el que nos hace conocer más, y nos muestra muchas diferencias. (ARISTÓTELES, 1982, p.2)

Aristóteles não apenas realça a visão ao dizer que ela é a mais amada de todos

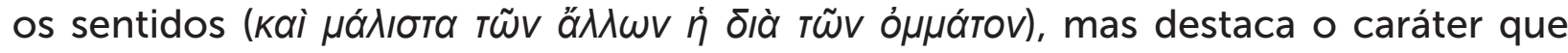
ela tem de nos instruir melhor, mostrando-nos as diferenças dos entes. Conjuga-se todo um embasamento reflexivo metafísico amparado na importância do olhar. $O$ olho mostra-se desde os primeiros momentos da reflexão literário-filosófica como fundamental para a apreensão do que nos cerca. O olho é aquele que nos coloca no mundo, revelando-nos ao mesmo tempo em que duvidamos aquilo que nossos olhos nos mostram. Neste apelo acerca da importância do olho, quase erótico, descortinase incessantemente o que nos circunda, enquanto que para deixar de ver necessitase de um ato aparentemente simples: fechar os olhos. Se em Sócrates já havia certa alusão à visão como sentido prioritário para o conhecimento na concisa fórmula "só sei (oída) que nada sei (ouk oída)", cuja tradução ao pé da letra seria "só vi que nada vi", ainda assim o seu nome encontra-se ligado ao método da dialética que leva seu nome, dialética socrática, conhecida também por maiêutica, em que o interlocutor de Sócrates chega à verdade através das próprias conclusões que vai obtendo. Pelo discurso, então, chegar-se-ia à elucidação ou manter-se-ia na dúvida inicial, configurando o que se denomina de aporia. Logo, o ouvido seria o órgão de destaque para Sócrates. O olho ganharia destaque notório apenas com Platão, como desejamos mostrar na passagem citada acima.

Para citarmos uma nova abordagem do olho mais próxima de nós e que se relaciona com este trabalho sobre Afrodite, somos transportados ao olho que percorre todo o relato de Histoire de l'oeil (1928) de Bataille que associa o olho ao ovo. $O$ conto de Edgar Allan Poe "The tell-tale heart" talvez tenha sido uma das influências literárias para a elaboração do relato de Bataille, embora não haja nenhuma referência explícita a este conto. No texto de Poe, o narrador, como ocorre frequentemente, certifica o leitor de que sua condição mental não se encontra abalada: “[...] but why will you say that I am mad? The disease had sharpened my senses - not destroyed - not dulled them" (POE, 2004, p.245), e o terror que o subjuga provém do olho de 
um cego que se parece com o olho de um urubu: "One of his eyes resembled that of a vulture - a pale blue eye, with a film over it." (ibid., p.245). Em resumo, o narrador deve matar esse homem simplesmente porque possui um olho demoníaco: "[...] for it was not the old man who vexed me, but his Evil Eye." (ibid., p.245). O olho da metafísica sofre mutações e revela a escuridão que nele se escamoteia.

O olho do crítico, por sua vez, pode ser visto como aquele que persegue seu objeto de desejo erótico sem nunca satisfazer-se com a sua leitura. Seguindo um fluxo aparentemente contrário ao apresentado no mito da caverna platônico, necessitamos no início deste percurso adentrar na caverna de Lascaux para dela extrair ao menos um tênue feixe de luz. O passo seguinte será olhar o nascimento de Afrodite. Eis que a deusa da beleza nos captura uma vez mais.

\section{Afrodite, o caos e a espuma}

Neste segundo movimento de nosso trabalho, apresentaremos a figura de Afrodite representada tanto nos textos da Grécia clássica, como em Hesíodo, quanto na sua gênese amplamente conhecida proveniente da espuma.

O crítico francês Didi-Huberman, ao analisar detidamente o que caracteriza a espuma e a sua forma, destaca o amorfo de sua composição físico-química: "[...] c'est la partie la plus vile et la plus informe de tout ensemble" (DIDI-HUBERMAN, 2007, p.74). Por sua vez, o nascimento de Afrodite está intimamente relacionado com a espuma, espécie de esperma do mar que não cessa de agitar-se. Logo, se quisermos acompanhar o pressuposto do crítico francês, há neste nascimento algo amorfo.

Na Teogonia de Hesíodo, como já apontado anteriormente, lemos o nascimento dos deuses, e entre eles a conturbada relação de Terra e Céu. Crono, filho de ambos, será destinado a exterminar o próprio pai, cujo ódio direcionado aos filhos os privava de ver a luz. O resultado deste parricídio será cantado em uma passagem que conserva o seu frescor pela violência do crime cometido, ao mesmo tempo em que permite aflorar das águas o máximo expoente da beleza grega. Acompanhemos as palavras do poeta:

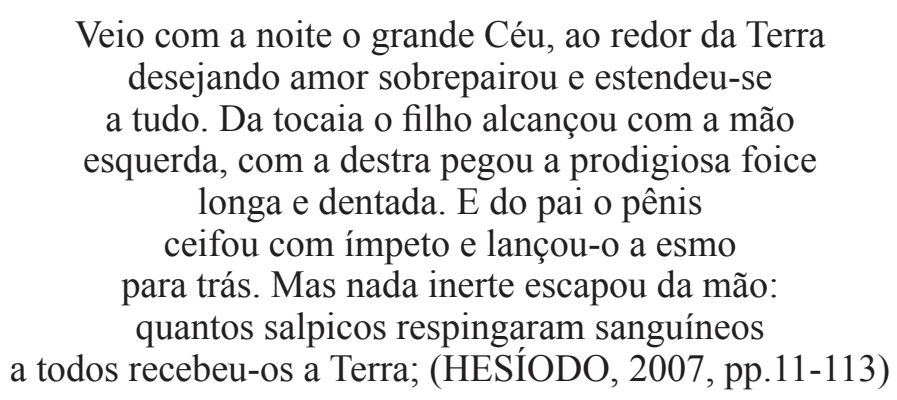

Nesta passagem, somos testemunhas do crime cometido pelo grande Crono de curvo pensar em colaboração com a mãe Terra, e alguns versos mais adiante presenciaremos o nascimento de Afrodite a partir do membro decepado:

O pênis, tão logo cortando-o com o aço

atirou do continente no undoso mar,

aí muito boiou na planície, ao redor branca

espuma da imortal carne ejaculava-se, dela 


\section{uma virgem criou-se. Primeiro Citera divina atingiu, depois foi à circunfluída Chipre \\ e saiu veneranda bela Deusa, ao redor relva crescia sob esbeltos pés. A ela. Afrodite \\ Deusa nascida da espuma e bem-coroada Citeréia apelidam homens e Deuses, [...] (ibid., p.113)}

Concomitante a este agitar da espuma vincular-se-ia um impulso esquizofrêni-

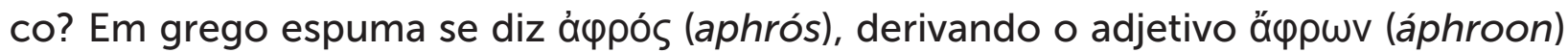
que para o português poderia ser traduzido por louco, demente, insensato. Portanto, ao nascimento de Afrodite, que para Didi-Huberman é "la naissance de la Beauté même" (DIDI-HUBERMAN, 2007, p.75), vincula-se o arrebatamento irrefreável

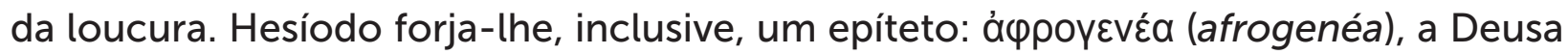
nascida da espuma. Mas não apenas da espuma, a semente cultivada nesta espuma é o pênis ceifado de Céu. E para dar cabo de tantas peculiaridades, Hesíodo enge-

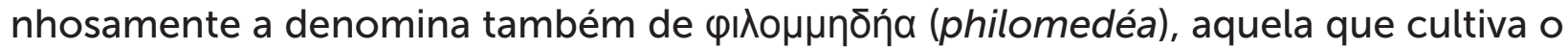
amor-ao-pênis. Vida, morte, desejo e beleza, uma mescla que Bataille certamente apreciaria, equivalendo tudo isto ao nascimento da deusa mais apreciada e cultuada no mundo antigo. Vênus, vertida ao idioma latino, cativa os romanos que lhe continuam rendendo homenagens, tanto em versos quanto nas artes. Emanando do mundo grego e ampliando a sua esfera de ação, o ardor por esta deusa é tanto que até mesmo uma pintura sua jamais vista é eloquente em suas cores e beleza graças aos textos gregos e latinos legados pelos antigos, principalmente através de Plínio, o Velho. O quadro em questão é a Afrodite Anadyomena, pintado por Apelles.

A análise crítica de Didi-Huberman colabora para compreender melhor o seu significado histórico dentro do contexto da história da arte. Justamente pelo fato de ser uma pintura inacessível a nossa contemplação in locu, ela se destaca como chef-d'oeuvre, e os fiapos de texto ("écheveau de textes" (ibid., 2007, p.70) são os únicos intermediários entre nós e a pintura. A relação entre pintura e escrita é posta em cheque; pode-se ver um quadro lendo apenas um punhado de palavras? Horácio, em sua poética ${ }^{3}$, afirma que:

Poesia é como pintura; uma te cativa mais, se te deténs mais perto; outra, se te pões mais longe; esta prefere a penumbra; aquela quererá ser contemplada em plena luz, porque não teme o olhar penetrante do crítico; essa agradou uma vez; essa outra, dez vezes repetida, agradará sempre. (HORÁCIO, 2005, p.65)

Ut pictura poesis (como a pintura (é) a poesia) é o topos abordado por Horácio na sua Poética, estabelecendo poesia e pintura como atividades artísticas próximas. Escrito há mais de dois mil anos, este topos ainda pode ser apreciado quando nos deparamos com esta pintura invisível. Se por um lado Gombrich interpreta esta pintura desaparecida como uma lacuna irreparável na história da arte

There is one gap in our knowledge which every lover of Greek art feels most keenly. We do not know the Works of their great painters about which the ancient

${ }^{3}$ De fato, trata-se de uma epístola dirigida aos Pisões (Epistula ad Pisones) em que Horácio dá conselhos e pareceres acerca do ofício do poeta. 
authors wrote with such enthusiasm. The name of Appeles, who lived at the time of Alexandre the Great, for instance, remained proverbial, but we have no work by his hand. (GOMBRICH, 2007, pp.631-632)

- por outro, acreditamos ser possível retomar esta pintura pela palavra escrita. O corpo de Afrodite molda-se na composição verbal, sanando a sua ausência por meio do corpo textual que lhe restitui o poder de apresentação. Entre os escritos sobre este quadro, destacamos o caráter que lhe foi atribuído de summum dito por Propércio. Estamos diante de um quadro perdido para o nosso olhar, corporificado somente na letra impressa. Afrodite encontra-se vagando incessantemente através dos textos:

[...] l'écume dont nous éclabousse l'Aphrodite d'Apelle, cette écume ne cesset-elle - pas de se répandre - car elle circule, elle passe de texte en texte - comme un mythe théorique, hyperbolique en tant que myhte, mais pas $<<$ faux $>>$ pour autant: un mythe relatif aux fins et aux moyens mêmes de la peinture. Elle en déploie aussi, nouée aux fins, comme une récitation des origines. (DIDI-HUBERMAN, 2007, p.73)

A recitação da origem, a perene busca pelo que vem sem provir de nada. Ou, ponderando de modo menos habitual, a busca pelo nada, pelo não-ser que já encontra-se exposto no poema de Hesíodo. Desde o Banquete de Platão, diálogo centrado na figura de Eros e os elogios a ele dirigidos pelos convivas, a questão concernente a Afrodite ganhou destaque e manifestou-se, por conseguinte, o seu aspecto duplo:

Todos sabemos que não existe Afrodite sem Eros. Se Afrodite fosse uma só, um só seria Eros. Havendo, porém, duas, há necessariamente dois Erótes. Como assim, duas? A mais velha, a sem mãe, é filha de Urano, a que chamamos Urânia. Atribuímos à mais nova, filha de Zeus e de Dione, o nome de Pandêmia. (PLATÃO, 2012, p.43)

A Afrodite que Platão denomina como sendo a mais velha e sem mãe (тоu

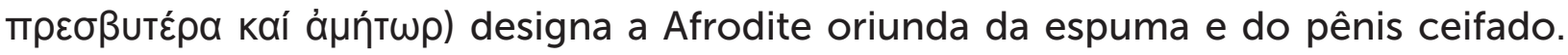
Ela é renomeada e passa a se chamar Urânia. Sua condição de órfã materna intensifica ainda mais a sua ligação com o crime cometido, pois Platão a vincula ainda de maneira mais forte com seu pai Urano. O peso do parricídio não abala Afrodite, e a leitura que dela farão os pensadores, filósofos, pintores e demais artistas consolidará sua presença sedutora e fechada no círculo de seu enigma.

\section{A presença de Afrodite na arte}

Como proposta de outra leitura possível, analisaremos como ao longo dos séculos Afrodite foi tema de inúmeros pintores e o seu nascimento atraiu a atenção; além de ter sido retratada de diversas maneiras, principalmente durante o Renascimento. Afrodite metamorfoseia-se, mantendo sua ambiguidade. Esta terceira parte do texto irá deter-se em alguns quadros, ilustrações e esculturas de Afrodite, com o intuito de destacar como esta figura foi sendo pensada ao longo de todas estas manifestações artísticas.

Em Ouvrir Venus. Nudité, rêve, cruauté Didi-Huberman irá efetuar uma leitura desde a Vênus de Botticelli até Madame Edwarda, de Bataille, publicado sob o pseu- 
dônimo de Pierre Angélique durante a $2^{\underline{a}}$ guerra mundial. Nas figuras abaixo podemos ver estas representações.

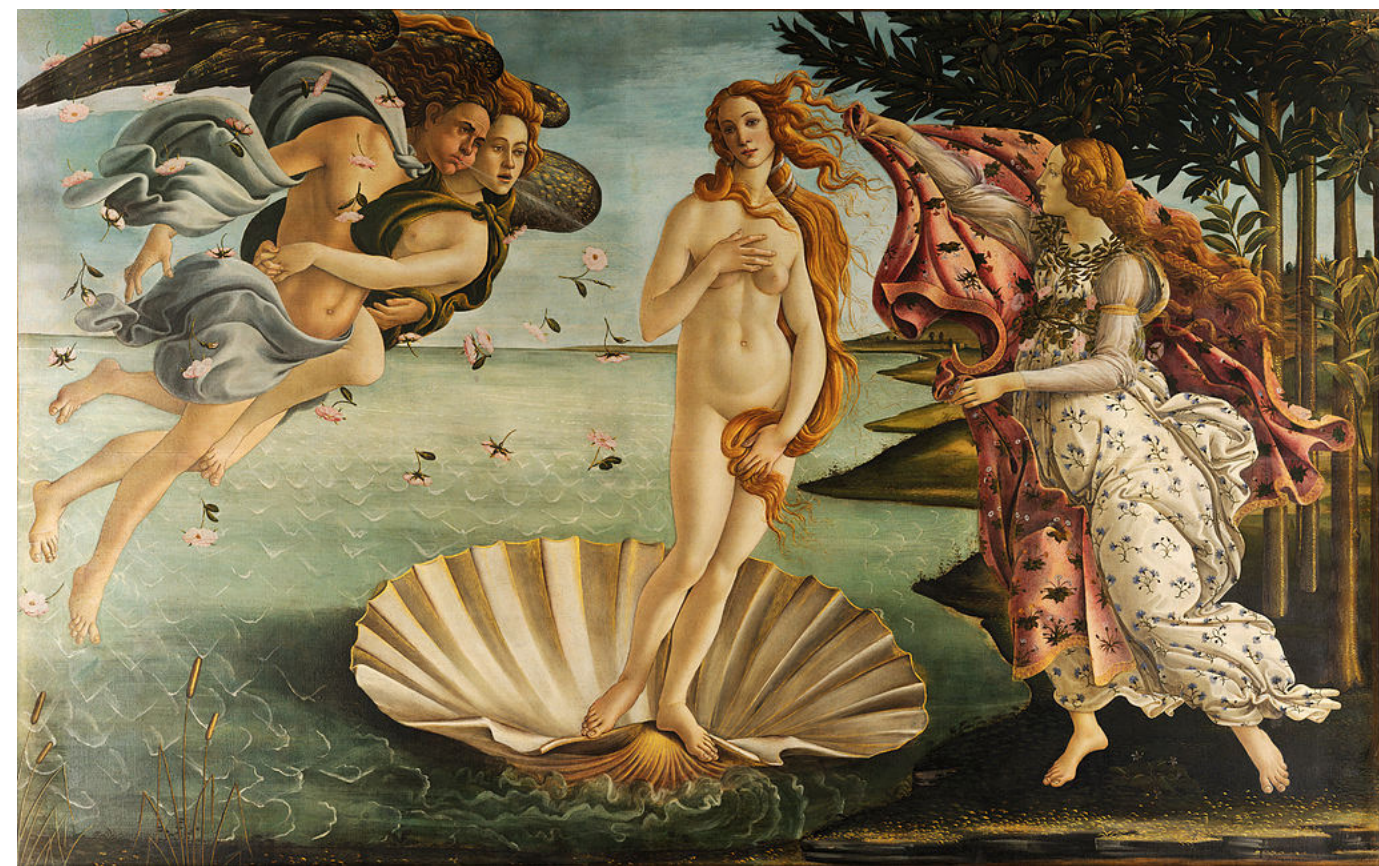

Figura 1. La nascita di Venere. Sandro Botticelli, 1486.

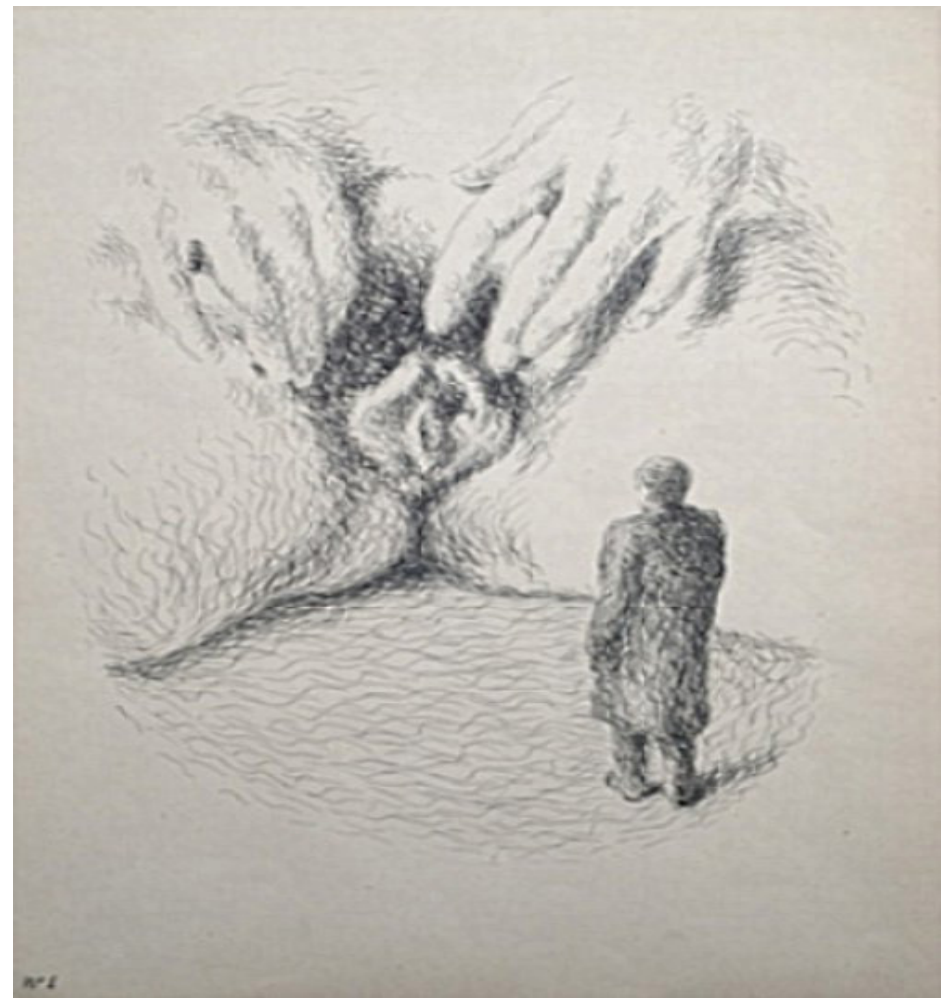

Figura 2. Ilustração para Madame Edwarda de René Magritte, 1946.

As diversas interpretações de Afrodite serão revisitadas por Didi-Huberman, trazendo à tona questões esquecidas e pouco discutidas. Nas primeiras páginas lemos a retomada do caráter duplo de Afrodite (Venus Coelestis e Venus Naturalis) no século $\mathrm{XV}$, e a consciência desta duplicidade por parte de Sandro Botticelli. Se o seu qua- 
dro O nascimento de Vênus aparenta salientar e retratar apenas os traços delicados, destacando o caráter sereno da Venus Coelestis, tal leitura reforça o lado ingênuo do espectador, pois, segundo o teórico francês (DIDI-HUBERMAN, 2005, p.45), Botticelli representa em inúmeros quadros a crueldade, bem como o erotismo. A reflexão de Didi-Huberman corrobora que a deusa da beleza está repleta de aspectos múltiplos (discutidos desde Hesíodo, e mais tarde por Platão), e se para ele o aspecto duplo revela-se ser a primeira impureza, isto se deve ao modo como ela foi concebida. Falar de Vênus celestial seria um eufemismo, pois ela surge da castração do Céu.

Os quadros analisados por Didi-Huberman concentram-se, sobretudo, em Botticelli e Clemente Susini, este último tendo representado a Venus desventrada no século XVIII modelada com cera colorida, conforme vemos na figura 3.

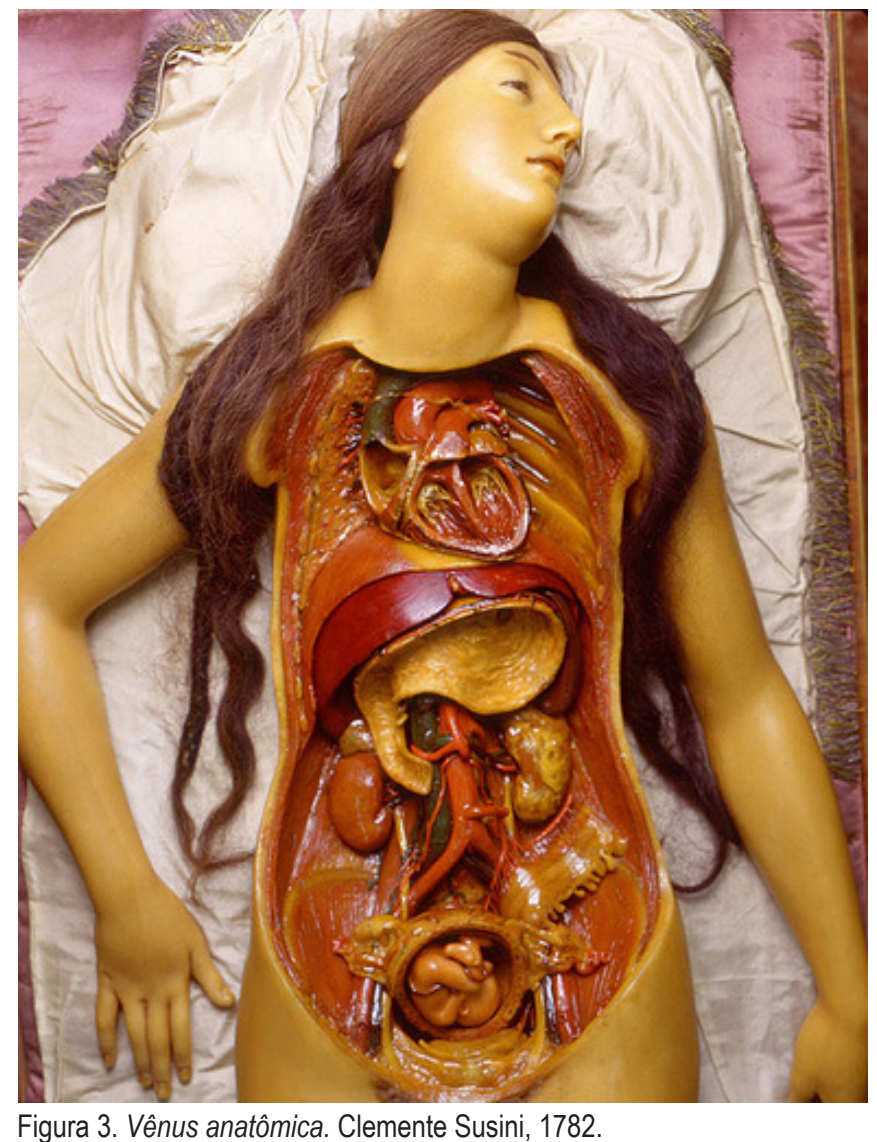

Contemplar esta Vênus pode causar vertigem, nossos olhos captam toda a massa interior de seu corpo e a beleza que ela nos transmite esgota-se na sua interioridade. A representação não está nas linhas e no contorno exterior; a eloquência pertence às entranhas. $O$ dentro expõe o corpo proibido aos olhos. $O$ amor de Vênus por Marte explode na cera de Susini, e toda a contradição é manifestada, rasgada. A deusa nos erotiza pelo que ela tem de humano, mortal e asqueroso.

Porém, ainda devemos ver uma das últimas 'Afrodites' analisadas por Didi-Huberman: Madame Edwarda. Lemos que "[...] el relato de Madame Edwarda se sitúa en muchos aspectos en los antípodas del mundo humanista de Boccaccio o de Botticelli." (DIDI-HUBERMAN, 2005, p.110). Bataille situa Madame Edwarda no centro de uma Paris tumultuada, ávida por diversão e escândalos noturnos. O périplo de Ma- 
dame Edwarda resume-se a satisfazer o chamado carnal, e para lográ-lo ela deve liberar-se do peso das roupas. Ela se exibe na nudez crua de seu ser. No prefácio somos advertidos do teor do relato: "eroticism is clearly shown as opening onto the consciousness of the wound in being." (BATAILLE, 2012, p.7) Ao longo do relato ela se identifica com Deus, e persuade o narrador a contemplar seu sexo:

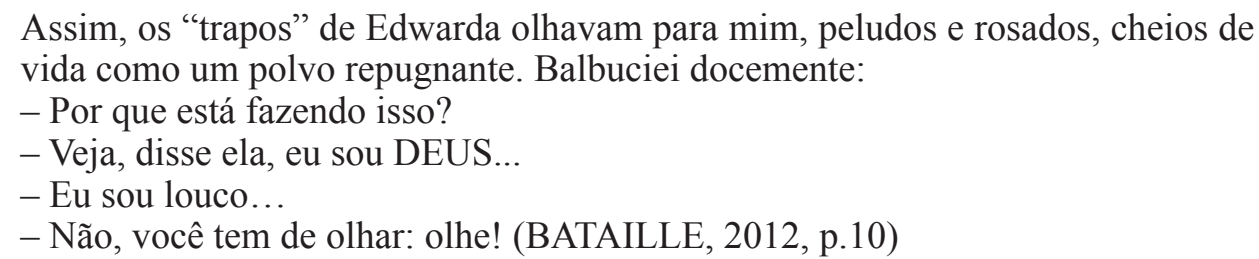

Estas palavras podem ser vistas dialogando com o quadro de Gustave Courbet (L'origine du monde - 1866), enquanto identificamos a importância que se dá ao olhar, pois Madame Edwarda reforça que ele deve ater-se ao centro de seu corpo, o que fica explícito no desenho de Magritte na figura 2.

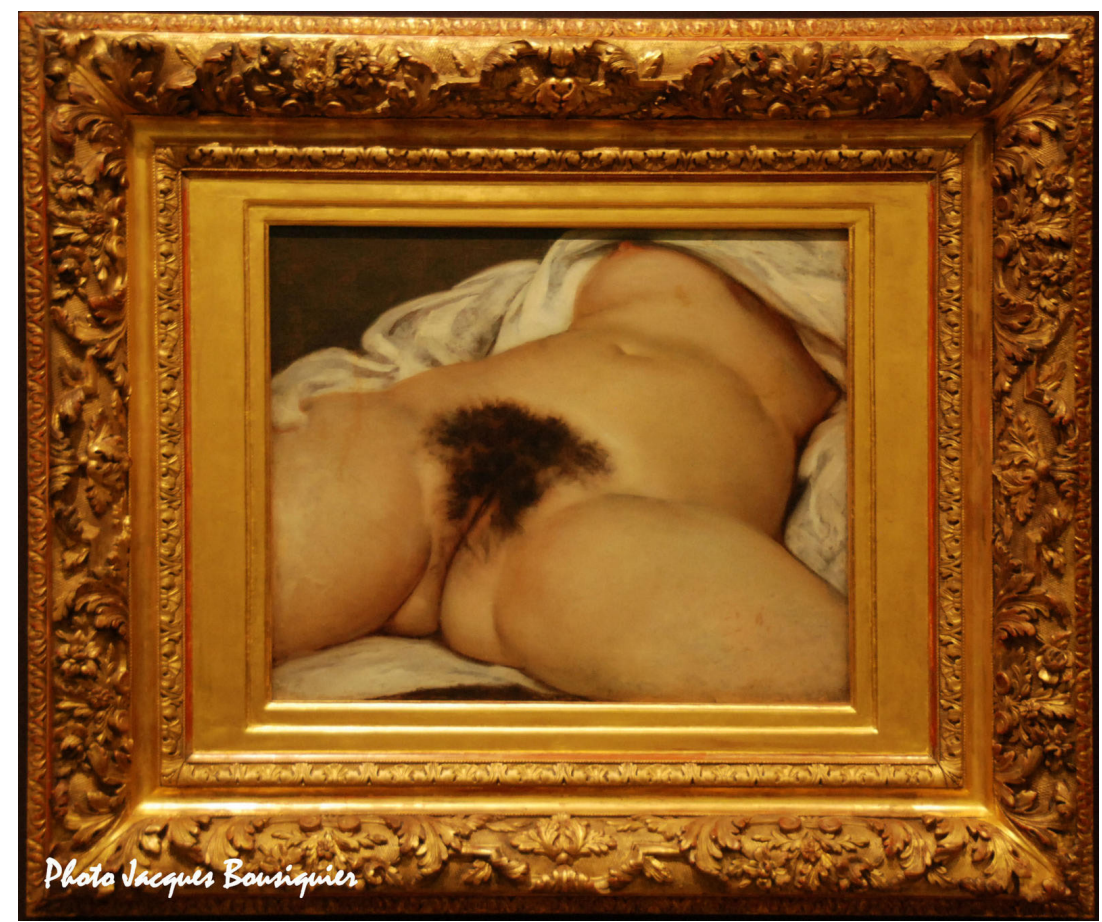

Figura 4. L'origine du monde. Gustave Courbet, 1866.

No quadro de Courbet, a nudez não se associa exclusivamente ao aspecto erótico, contrariamente ao relato de Bataille. O próprio título da obra destaca a origem do mundo e não do homem; ao contemplar L'origine du monde não desejamos penetrar aquele corpo feminino, está-se diante da origem cósmica. Entretanto, em Bataille e Courbet o olho do espectador é transportado ao mesmo ponto central.

Assim, nesta imersão pelas diversas representações de uma deusa, cujo nascimento ficara caracterizado pelo enigma, desde os gregos, passando pela pintura, pela literatura, até a leitura contemporânea de Didi-Huberman, procurou-se destacar o caráter ambíguo que permeia toda a sua força interpretativa. Desta forma, desejouse não optar por esta ou aquela linha argumentativa, mas sim, residir nessa potência tão característica de Afrodite. 


\section{BIBLIOGRAFIA:}

ARISTÓTELES. Metafísica. Edición trilingüe, traducción de Valentín García Yebra. Madrid: Gredos, 1982.

ARISTÓTELES, HORÁCIO, LONGINO. A poética clássica/Aristóteles, Horácio, Longino. Tradução de Jaime Bruna. São Paulo: Cultrix, 2005.

ARTAUD, Antonin. El teatro y su doble. El pesanervios [Le théâtre et son double 1935. Le pése-nerfs. - 1925]. Madrid: Editora Nacional, 2001.

BATAILLE, Georges. Madame Edwarda. Disponível em pdf: http://escritablog.blogspot.com.br/2012/04/madame-edwarda-de-georges-bataille.html

DIDI-HUBERMAN, Georges. Venus rajada. Desnudez, sueño, crueldad [Ouvrir Venus. Nudité, rêve, cruauté - 1999]. Traducción de Juana Salabert. Buenos Aires: Losada, 2005.

DIDI-HUBERMAN, Georges. "La couleur d'écume ou le paradoxe d'Apelle" in: L'image ouverte. Motifs de l'incarnation dans les arts visuels. Paris: Gallimard, 2007.

GOMBRICH, E. A. The story of art. New York: Phaidon, 2007.

HESÍODO. Teogonia. Estudo e Tradução de Jaa Torrano. São Paulo: Iluminuras, 2007. NIETZSCHE, Friedrich. Além do bem e do mal [Jenseits von gut und Böse - 1885]. Tradução: Lilian Salles Kump. São Paulo: Centauro, 2006.

NIETZSCHE, Friedrich. Ecce homo [Ecce homo: wie man wird, was man ist - 1888]. Tradução: Paulo César Lima de Souza. São Paulo: Companhia das Letras, 2008.

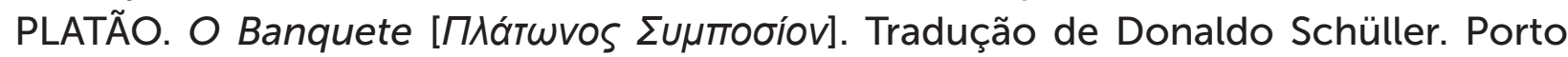
Alegre: L\&PM, 2012.

PLATÓN. República. Traducción de José Manuel Pabón y Manuel Fernández-Galiano. Madrid: Alianza Editorial, 2005.

POE, Edgar Allan. The complete illustrated works of Edgar Allan Poe. London: Bounty Books, 2004.

PRESOCRÁTICOS. Fragmentos I. Traducción y notas: Ramón Cornavaca. Buenos Aires: Losada, 2008. 